\title{
Review: \\ The invasion of Acacia nilotica in Baluran National Park, Indonesia, and potential future control strategies
}

\author{
SHAFIA ZAHRA", RICHARD W. HOFSTETTER, KRISTEN M. WARING, CATHERINE GEHRING \\ School of Forestry, Northern Arizona University. 200 East Pine Knoll Drive, Flagstaff, Arizona-86001, USA. Tel./fax. +1 928-523-3031, \\ •email: shafia.zahra93@gmail.com
}

Manuscript received: 29 August 2019. Revision accepted: 10 December 2019

\begin{abstract}
Zahra S, Hofstetter RW, Waring KM, Gehring C. 2020. Review: The invasion of Acacia nilotica in Baluran National Park, Indonesia, and potential future control strategies. Biodiversitas 21: 104-116. Acacia nilotica, commonly called prickly acacia, is infamous for its ability to invade various ecosystems, especially savannah. The tree was introduced to Baluran National Park (BNP), Indonesia in 1969 and nowadays has invaded more than 50\% of BNP savannah habitat. Its presence has had significant negative impacts on local flora and fauna of the park. Physical and chemical eradication efforts of this plant have been conducted in the park but these have failed. Little is known about the tree invasion in Indonesia and no control suggestions have previously been proposed. Here, we review the causes and history of the invasion of this tree, describe previous attempts to eradicate the tree, and provide possible containment and control strategies. We describe 12 strategies based on successes and failures to control this tree in Indonesia and other countries and divide the methods into four categories: (i) physical: girdling the trunk, uprooting with winch, manual seedling uprooting, defloration, and restoration with fire; (ii) chemical: using biochar or herbicides; (iii) biological: using native plant competitors (grasses, shade trees), predators (insect) and pathogens (fungi) or microorganisms; (iv) social: centralized tree utilization, education outreach, and stakeholder collaboration. We summarize the relative effectiveness and efficiency of each method and explain how to integrate the aforementioned methods to help authorities choose the most appropriate strategies for their resources, needs and goals.
\end{abstract}

Keywords: Acacia, biological control, invasive species management, savannah restoration

\section{INTRODUCTION}

Acacia nilotica also known as Vachellia nilotica (Kyalangalilwa et al. 2013) (synonym Acacia subalata, A. scorpioides, A. arabica, Mimosa arabica, and M. nilotica), is commonly called the prickly acacia and belongs to the Fabaceae family. The prickly acacia is native to the Indian subcontinent, Middle East, and Myanmar. The tree has invaded Indonesia, specifically in Baluran National Park (BNP) since 1969 (Alikodra 1987). The invasion has caused a reduction in species abundance and biodiversity in the park. Physical, chemical, biological, and social attempts to control the spread of the trees in the park have had limited success. A comprehensive review and evaluation regarding control methods in the park have not been conducted. Here, we compile information on the natural history of A. nilotica, causes of invasion, history of the invasion, and evaluation of previous control methods in BNP. We highlight and formulate potential control strategies for the acacia in BNP based on previous control efforts in BNP and in other countries. We hope this review will fill the knowledge gaps and provide a bigger picture to tackle the problem.

\section{The natural history of Acacia nilotica}

The prickly acacia is a woody plant that grows up to 1215 meters. It has one main trunk with a broad round-shaped canopy, dark brown bark with a rough surface and $10 \mathrm{~cm}$ long silver thorns (often in pairs). The acacia has bipinnate leaves which consist of 2-11 pairs of pinnae and 7-25 pairs of leaflets (Schmidt and Mbora 2008), ranging in number and size from 1-7 x 0.5-1.5 mm (Djufri 2004). The yellow globular-shaped flower is $1.2-1.5 \mathrm{~cm}$ in length, nectar-less, with bees (Megachilidae and Anthoporidae) as the main pollinators, and mostly are male with few hermaphrodites (Tybirk 1989). The seed is oblong-shaped, 61/2-11 mm long, $12-14 \mathrm{~mm}$ wide, $3.5-4 \mathrm{~cm}$ thick, extremely hard coated with dark brown color and white pleurogram (Schmidt and Mbora 2008). Typically, 8-12 seeds are protected inside woody leathery pods (Coates-Palgrave 1984) with little or no constriction (Schmidt and Mbora 2008) and indehiscent (Lamprey et al. 1974). Flowering and fruiting seasons are affected by temperature (Schmidt and Mbora 2008). In BNP, flowering season occurs between April and June and seed production occurs between July and August (Djufri 2012). Mature trees can produce 14 to 3150 pods each year or, on average, 832 pods per tree (Djufri 2004). Seeds usually propagate well in riparian areas (Brown and Carter 1998). Adult trees can re-sprout from cut stumps (Setiabudi et al. 2013). Fire may promote germination through scarification (Van Etten 2016).

Many animals and pathogens feed on or affect the growth of the prickly acacia in its native habitat. The most important natural enemies of the prickly acacia are likely insects such as seed predators, e.g., Bruchidius uberatus, Pycobruchidius latiorthorax, Caryedon fasciatus (Miller 
1994a), Melanterius weevils (Impson and Hoffmann 2019) or herbivores, such as the bagworm moth Pteroma plagiophleps (Pillai and Gopi 1990). Rodents (Miller 1994c) and the camel Camelus dromedarius (Tybirk 1989) also feed on seeds or plant tissues. Termites are known to colonize and feed on the wood and marine borers (mollusks) may feed on wood or roots that are within water (Tewari 1978). Plant fungal pathogens such as Drechslera, Aspergillus, Alternaria, Rhizopus, Fusarium, and Mucor (Javaid and Akhtar 2006; Ahmad et al. 2017) are reported to cause prickly acacia dieback in Pakistan. In India, Fusarium oxysporum causes a vascular wilt disease on the seedlings (Kapoor et al. 2004).

Animals play an important role in dispersing the prickly acacia seed. Many animals ingest the seeds and spread them through feces. These include large mammals e.g., giraffes Giraffa camelopardalis and African elephants, Loxodonta africana, ungulates e.g., the kudu, Tragelaphus strepsiceros and the impala, Aepyceros melampus (Miller 1994c), antelopes e.g., Antidorcas marsupialis, Raphicerus campestris, Sylvicapra grimmia, and birds e.g., the ostrich Struthio camelus (Miller and Coe 1993; Miller 1994b; Miller 1996). Increased dispersal distance, away from the parent tree can reduce seed predation by bruchid beetles (seed insects) (Miller and Coe 1993; Miller 1994a; Miller 1994b). Seeds that have been passed through an ungulate's gut have an $81 \%$ higher chance of germinating (Harvey 1981).

\section{The invasiveness of Acacia nilotica}

Acacia nilotica is well known for its ability to invade habitats (Kriticos et al. 2003). The tree has many features that favor establishment and invasiveness. These features include, but are not limited to, allelopathy (Djufri 2004), broad environmental tolerance (Brown and Carter 1998; Fagg 1992; Kaushik and Mandal 2005), low predation and herbivory rates (Palmer et al. 2005), mycorrhizal associations (Sharma et al. 2001), and high seed production and dispersal (Djufri 2004).

Allelopathy is a phenomenon by which one organism produces biochemicals that negatively or positively influence the growth, survival, and reproduction of other organisms (Einhellig 1995). Allelochemicals are chemical substances exuded by plants, algae, bacteria, coral or fungi (Rizvi et al. 1992) that are used as a defense (Latif et al. 2017). In terms of plants, the chemicals come from leaf or stem leachates, volatiles, root exudates, or decomposition of plant residues (Rizvi et al. 1992). Allelochemicals interrupt physiological processes such as respiration (CruzOrtega et al. 1998), photosynthesis (Meazza et al. 2002), and water and nutrient uptake (Bergmark et al. 1992) in neighboring plants. They also inhibit cell division and elongation (Nishida et al. 2005), disturb the balance of the antioxidant system (Bais et al. 2003), alter the composition of growth phytohormones (Yang et al. 2005) and increase cell membrane permeability (Lin et al. 2000). Prickly acacia contains allelochemical substances such as gallic acid, m-digallic acid, catechin, chlorogenic acid, gallolyated flaven-3, 4-diol and rabidandiol (Malan 1991) in the form of tannins which are concentrated (up to 16\%) in their bark and pods (Suhati 1990 in BNP 2006a). The plants extract has been proven to negatively affect crops such as maize (Hussain et al. 2019) and fenugreek (Choudhari et al. 2019).

The tree's success in survival, growth, and spread can also be attributed to its ability to tolerate a wide range of abiotic conditions such as heavy rainfall and drought (Brown and Carter 1998), heat (Fagg 1992) and infertile soil (Kaushik and Mandal 2005). In their native area, their tolerance towards environmental factors is likely due to the association with native arbuscular mycorrhizae (AM) (Sharma et al. 2001). Prickly acacia seeds have higher tolerance toward salinity when the seeds are inoculated with arbuscular mycorrhizae (Glomus fasciculatum) (Giri et al. 2007). It is unknown if the prickly acacia is able to associate with non-native AM species. Additionally, prickly acacia when planted along with native and nonnative rhizobium inoculates have higher biomass than the trees that are not planted alongside the rhizobia (Lal and Khana 1993). Rhizobia are bacteria which live in root nodules of legumes and provide nutrients and fixate nitrogen to the plant. Most rhizobia have a high tolerance for drought and low pH (Zahran 1999).

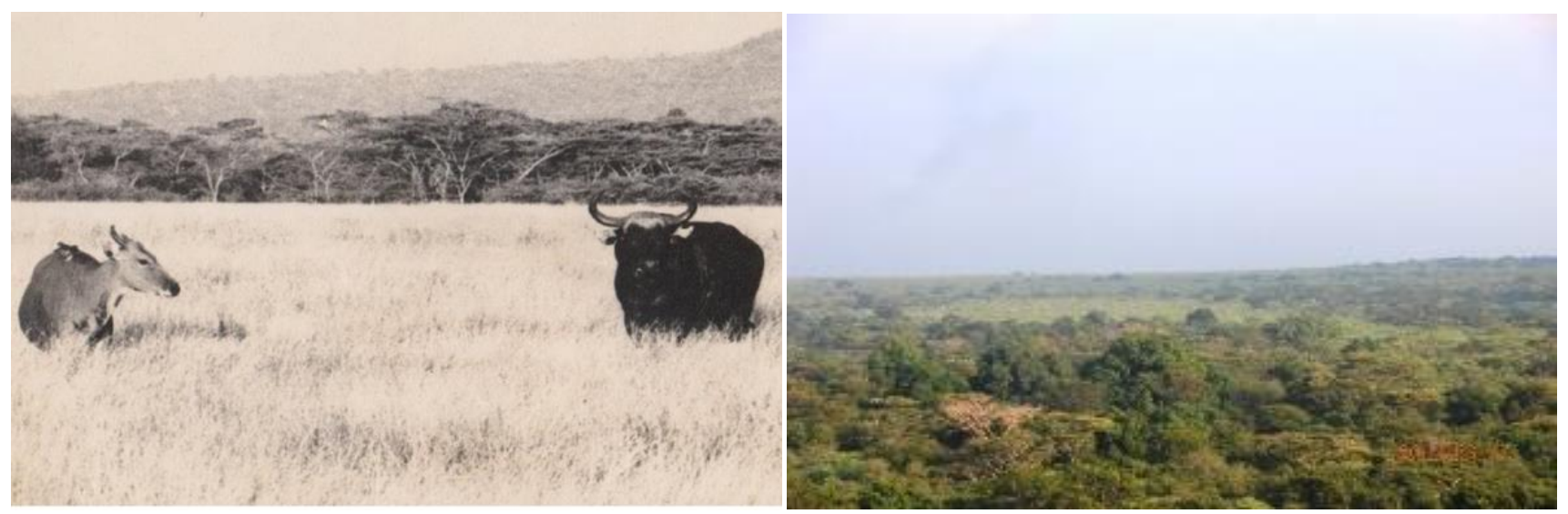

Figure 1. Savannah in Baluran National Park before the invasion of Acacia nilotica (left; Source: BNP 2017). After the invasion from the observation tower (right; Photo: Shafia Zahra) 


\section{Baluran National Park}

Baluran National Park (BNP) is located in East Java, Indonesia and geographically lies between S 7²9'10'-S 7'55'55" and E 114'29'20"'-E 114'39'10" (BNP 2010). The national park consists of savannah, mangrove, and coastal, lower mountain, swamp, and deciduous forests. This national park has an extent of 25,000 hectares, is dominated by savannah (40\% of park area) and contains the largest savannah area on the island of Java (BNP 2010). The savannah is habitat for many charismatic species such as the endangered bull-like species Bos javanicus or banteng (Gardner et al. 2016), Pavo muticus or the green peafowl (BirdLife international 2018a), Cuon alpinus or dhole (Kamler et al. 2015), the vulnerable Panthera pardus or leopard (Stein et al. 2016), Trachypithecus auratus or Javan langur (Nijman and Supriatna 2008), and the nearthreatened Buceros rhinoceros or rhinoceros hornbill (BirdLife International 2018b).

\section{History of Acacia nilotica as an invasive species in Baluran National Park}

The prickly acacia was first introduced to Indonesia around 1850 from the Indian Calcutta Botanical Garden to Bogor Botanical Garden (Schuurmans 1993). The purpose of its introduction was for rubber production, but the gum product did not meet expectations (Sastrapradja 1978). The original stump in Bogor Botanical Garden was later destroyed, 40 years after its introduction (Schuurmans 1993). Interestingly, this initial introduction did not result in the acacia establishing in this area at that time.

Introduction of the prickly acacia to BNP likely occurred in the early 1960s (Nazif 1998). The trees were planted as buffer zones or living fences between the National Park and teak plantations managed under the commercial forestry department. In 1969, trees were planted in BNP as firebreaks between the savannah and deciduous forest (Alikodra 1987; Schuurmans 1993). The planted area was $1200 \mathrm{~m} \mathrm{~km}$ long and $8 \mathrm{~m}$ wide (Tjitrosoedirdjo 2002). From that introduction, the tree has spread rapidly throughout the savannah of BNP. Wild ungulates and cattle feed on the seed assisted the dispersal of the tree (BNP 2017). Rains may help the dispersion of the seed as well as uncontrolled human activities within the national park. Before the invasion, banteng was seen grazing in the thick and vast grassland with native acacia trees (Acacia leucophloea) as shade trees around the savannah (Figure 1, left). The acacia outcompetes most native plants, especially in the savannah areas. The invasive acacia currently covers half of the original savannah habitat (Figure 1, right).

The prickly acacia has continued to spread since its introduction. Tree stem density was approximately 75 trees/ha in 1981, increased to 3337 trees/ha in 1986 and 5369 trees/ha in 1987 (Tjitrosoedirdjo 2002). In 1993, the total invaded area was \pm 1200 ha, consisted of \pm 420 ha of Bekol savannah, \pm 600 ha Balanan savannah, \pm 200 ha Kramat savannah (Schuurmans 1993). A study in 2013 found that tree density had peaked at 5592 trees/ha (BNP 2013). The tree has also invaded other ecosystems in the park: shrub, coastal forests, production forests, and lowland deciduous forests (BNP 2013).

\section{The effect of Acacia nilotica invasion and its mitigation efforts in Baluran National Park}

As of 2016, the prickly acacia has invaded more than 6000 hectares of BNP (Padmanaba et al. 2017) and recently not only invading savannah but also the dry forest in BNP (Sutomo et al. 2019). The invasion is predicted to be more severe in the future due to climate change (Sutomo and Etten 2017). Despite the invasion severity, the nutrient contents in the savannah soil remain stable (Samsoedin and Siregar 1997). Based on the Habitat Suitability Index (HSI), the eastern part of the coastline area of Indonesia will likely be more prone to invasion (Sutomo and Etten 2017). East Java, Bali, Lombok, Sumba, Kupang, and West Papua have the highest risk, as trees have already reached Bali and Kupang (Sutomo and Etten 2017). However, the model did not incorporate the effect of climate change on native species that potentially interact with the prickly acacia. The model also did not consider ungulate-seed dispersal, which can disperse the seed great distances. Further research regarding tree dispersal, reproduction, and mortality rates is needed.

The invasion of prickly acacia is one of the several factors that contribute to the decline of ungulate diversity and population (Setiabudi et al. 2013). The tree suppresses the growth of grasses (Tjitrosoedirdjo et al. 2013) which leads to the reduction of flora diversity and abundance (Caesariantika et al. 2011). The reduction of grass biomass (Qirom et al. 2007) and productivity (113 kg/day) is lower (BNP 2006c) than the standard (150 kg/day) (Wind and Amir 1997 in BNP 2006c). This reduction severely affects forage quantities for ungulates. Although there is no research directly linking grass biomass and ungulates' population decline, there is evidence that supports the hypothesis that ungulate population decline correlates with an increasing spread of prickly acacia. Prior to the invasion (in 1965), 250 bantengs were recorded in BNP. This number declined to between 161 and 194 individuals in 1984 (Sugardjito 1984). In 2011 there were only 22 bantengs left and the species is predicted to go extinct by 2050 (Hakim et al. 2015). The green peafowl population at BNP also declined by 52\% from 1988 to 2010 (Hernowo et al. 2011). Most research in BNP focuses on charismatic and flagship animals such as banteng and the green peafowl, but the effect of the trees on density of many species is probably overlooked.

Physical methods such as slash and burn have been used to control the prickly acacia since 1985 yet these efforts have only resulted in $20 \%$ of the targeted area cleared after 20 years of application (Garsetiasih and Siubelan 2005). Manual uprooting of seedlings has also occurred since 1994 (BNP 2007; 2017). In 2007, all the cleared area was reported to be re-invaded and from 2008 onwards, the control and containment were only conducted in prioritized area such as the Bekol savannah (BNP 2017). Using the same methods, it would take until 2072 to clear the prickly acacia from its present-day locations, but this would not include areas where it would spread or its re- 
invasion into areas already cleared (BNP 1999a). The failure in these methods is caused by the ability of $A$. nilotica to regenerate, cutting resulted in re-sprouting trunks with denser canopies (BNP 2006a) (Figure 2.A). Burning may kill the adult trees if done correctly (BNP 2006a) and help the native grasses to regenerate (BNP 2004) but the acacia appears to re-establish after fires (Caesariantika et al. 2011). Acacia seeds have a high tolerance towards fire (BNP 2004) and heat promotes germination of seeds through scarification (Van Etten 2016). Using manual labor, seedlings and re-sprouting stumps can be removed (e.g., 9 people can uproot 35 seedlings and 35 re-sprouting stumps within a day in a 50 $\mathrm{m} \times 100 \mathrm{~m}$ plot). Although the method is considered as the safest method and might be effective if done continuously, spotting the seedlings which can be as small as $3-5 \mathrm{~cm}$ in size among high grasses in savannah is time-consuming and labor-intensive (BNP 2005; 2007). Another physical method is pulling out mature trees with a bulldozer (BNP 2006b). This process destroys and disturbs the soil structure (BNP 1999) and promotes the establishment of other invasive species such as Lantana sp. and Thespesia lampas (BNP 2006a). Restoring the fire cycle in the ecosystem is performed to regenerate and establish more savannah habitat (BNP 2017) although the evaluation of the method on acacia has not been conducted. A new approach of using more efficient uprooting machines called a tirfor or winch is proposed but not yet applied or evaluated (Zakaria 2012).

Chemical control methods have been used in BNP since 2011 (BNP 2017). In total, there are five chemical substances used to kill the trees. Systemic herbicide, Indamin $720 \mathrm{HC}$ and 2,4 D dinitrophenol which works as a hormonal inhibitor were injected into the trunk of trees (Santoso 1986 in BNP 2006a) and able to kill trees with dose 40 cc (Nazif 1988). The use of $\mathrm{H}_{2} \mathrm{SO}_{4}$ on chopped stumps is proven to kill the stump within 25 days and is most effective if applied in the dry season and if the stump is covered with plastic bag (BNP 2006a). Applying kerosene and solar to the surface of the stump has not been effective. Other herbicides used are Garlon 480 EC (BNP 2006a) and Triclopyr diluted in diesel oil (Tjitrosoedirdjo et al. 2013) applied to peeled trunks $(15 \mathrm{~cm}$ and $10 \mathrm{~cm}$ above the ground respectively, Figure 2.B). Garlon 480 EC has not effectively killed trees while Triclopyr resulted in high tree mortality, about $89 \%$ tree death (Figure 2.C). Despite some successful attempts, chemical methods have a major drawback which is soil contamination as clay minerals in BNP soil are reported to be reactive and will likely adsorb the herbicide (Garsetiasih and Siubelan 2005). The use of $\mathrm{H}_{2} \mathrm{SO}_{4}$ may harm applicators (BNP 2006a). Unfortunately, there has been no research conducted on the effect of these chemicals on native species and soil organisms in BNP. The cost of using herbicides is significant and often not reasonable. Other research shows that extracts of Lantana sp. are able to prevent the germination of A. nilotica seeds and might be used as a natural herbicide, but further research is needed (Mirnawati et al. 2017).

Biological attempts that have been conducted by authorities include planting native shelter trees and grasses. Since 2009, six species of grasses, Themeda arguens; $T$. triandra; Dichanthium caricosum; D. queenslandicum; Polytrias amaura; Sorghum arundinaceum are planted to restore ecosystems and provide food for ungulates (BNP 2017). These grasses are the main grasses that comprise the savannah ecosystem. Shelter trees have also been planted since 2010 involving 4 species of trees: Azadirachta indica, Schleichera oleosa, Acacia leucophloea, and Tamarindus indica (BNP 2010). However, many of the seedlings of these species are eaten by deer and other ungulates (BNP 2010). Further research about the ability of grasses to grow and what factors affect them should be conducted. Additionally, five insect species were found to feed on the prickly acacia seeds (Caryedon serratus, Dinoderus sp., Pyralidae larvae, and Stathmopoda sp.), and these insects reduced seed numbers and seed mass (Pratama 2014). Further research regarding other organisms that may utilize the tree is still ongoing (Zahra 2019).
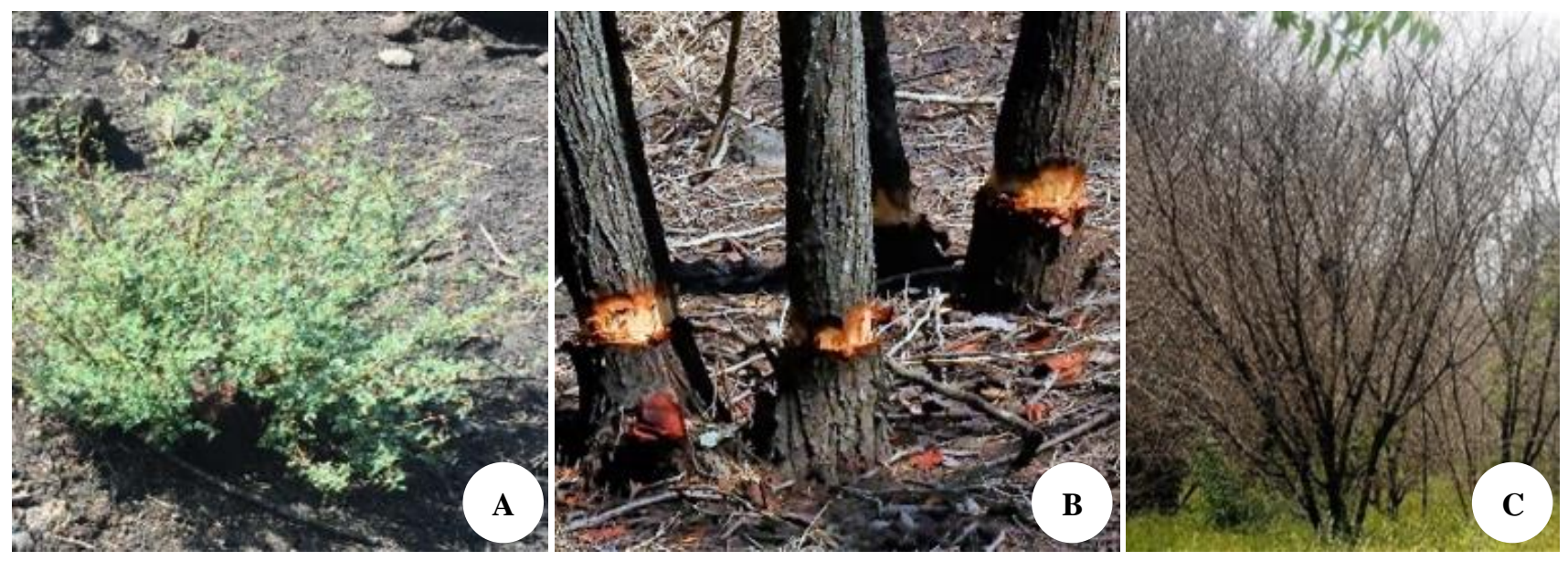

Figure 2.A. The branches re-sprout from the stump of Acacia nilotica (Photo: R. Hofstetter). B. Trunks of Acacia nilotica is smeared by herbicide after being debarked in Baluran National Park (Photo: E. Josen). C. The dried trees after the herbicide application (Photo: S. Zahra) 
Social efforts conducted around BNP include the harvest of $A$. nilotica seeds as a coffee mixture, sprouts as vegetables, and timber as firewood (Lydiasari 2016). However, the activity is not prudently managed which has resulted in the spread of seeds by local people either intentionally or unintentionally (BNP 2017). Other efforts include prohibiting cattle to graze in areas near the invaded area (BNP 2017). Education, socialization, and volunteering activities are not conducted yet.

\section{Potential management strategies to control Acacia nilotica in Baluran National Park}

According to the Global Invasive Species Program (GISP) there are four actions that can be taken to prevent the spread of invasive species: eradication, containment, control, and mitigation. Eradication is a rapid action that is conducted to directly and immediately eliminate the invasive species. Eradication is more effective if conducted in the early stages of invasion when the species only occupies a small area or if there are only a few individuals of the invasive species. The downside of eradication is that it is expensive, labor-intensive, and risky, as eradication methods can affect the ecosystem significantly or individuals of the invasive species are missing. If eradication is not feasible, containment should be attempted. The goal of containment is to prevent further spread of the invasive species. Control aims to reduce the abundance and density of the invasive species over the long term. This action is cheaper than eradication and it can be conducted in parallel with containment. Control could eventually lead to the eradication of the invasive species and restoration of the ecosystem. If the three attempts fail, the last option is to mitigate the effect. This action is more focused on saving the remaining native species from the effect of the invasive species, which may include relocation.

Based on the invasiveness of the prickly acacia in BNP, we propose and describe 15 potential methods to contain and control the prickly acacia in BNP. We also categorize them into four categories, physical, chemical, biological, and social. These strategies are based on our own observations and control efforts from other countries via literature searches and personal communication. These strategies can be integrated or applied separately. Integrated strategies may work more effectively yet could be expensive. We summarize the difficulty and requirements of each strategy.

\section{Physical methods}

Physical efforts can be effective if managed correctly or combined with other methods. Restoring a regular fire regime should be maintained to restore the ecosystem. Adult acacia trees can be removed by girdling (i.e. removing the bark; GISP 2001) and winch uprooting (Zakaria 2012). Girdling or cutting the cambium and removing five $\mathrm{cm}$ depth of the trees' bark will interrupt the nutrition transport and kill the tree (GISP 2001). In Portugal, authorities have successfully controlled multiple ( 6 species) invasive acacia species by stripping the bark off of the bottom of the trees, from the ground to $1.5 \mathrm{~m}$ up along the trunk (Figure 3). Bark stripping can be performed very quickly with minimal tools and effort. Bark-stripping has proven to kill trees within a few weeks with minimal re-sprouting (Invasoras 2012). Studies are needed to check the efficacy of bark stripping prickly acacias in BNP. This method could be an environmentally friendly method and reduce the use of herbicides. Seedling uprooting is easy and suggested to reduce eventual tree density. Flower harvesting can be sued to reduce seed production (Wilson et al. 2011). In general, physical methods are inexpensive but labor-intensive. Physical methods could be easily integrated with social methods (described later in the paper).

\section{Chemical methods}

Chemical methods can be harmful to the environment, but controlled and appropriate usage can be effective. In Australia, the herbicides aminopyralid/fluroxypyr was sprayed on the leaf surface and reduce the above-ground biomass (Vitelli and Pitt 2006). Splatter gun (Campbell et al. 2019) and Skattergun (March and Vogler 2018) were also used to reduce the labor on applying the herbicide. However, using herbicides and other chemical substance seldom result in long-term control and may cause serious side effects on non-target species. For example, applying natural herbicides such as Lantana sp. extract (Mirnawati 2017) is risky as it consists of allelochemical which might prevent neighboring plants to grow. More effort is needed to evaluate the usage and potential effect of chemicals in BNP.

Alternatives to chemical treatments include the use of biochar to absorb the allelochemicals of the invasive species and improve the soil. Activated carbon or biochar is known for its ability to rejuvenate soil by adsorbing phenolic compounds, e.g allelochemical in the soil (Wardle et al. 1998). The use of biochar from maize stalks and coconut husk feedstock is proven to counteract the allelopathic activity of strawberry guava and lemongrass (Sujeeun and Thomas 2017). Biochar can promote seed germination and early seedling growth of some plant species (Sujeeun and Thomas 2017), but can also be expensive. Additional research is needed to determine the benefits of using biochar and whether it will benefit remaining prickly acacia plants in the park.

\section{Biological control}

Biological control is one of the least explored options to control A. nilotica in BNP. Biological control methods can target various natural interactions such as multitrophic interactions, predators, competitors, and microorganisms. The drawbacks of this method are that it is timeconsuming, some might be expensive, quite risky if not backed up by adequate knowledge, labor-intensive and require a significant amount of research and monitoring. However, biological control might be a long-term option and provide additional benefits such as increasing ecosystem function and services. 


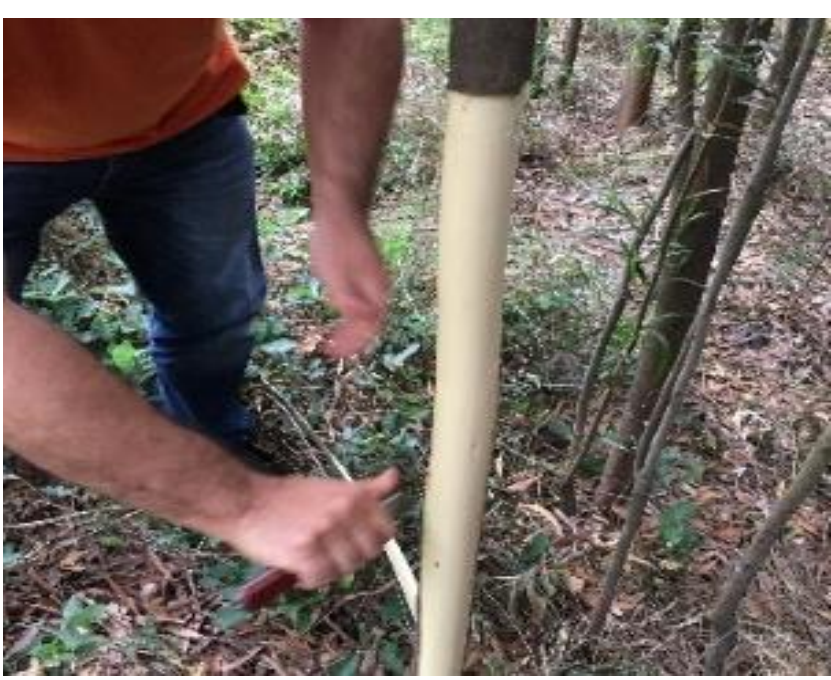

Figure 3. Debarking the acacia tree in Portugal (Photo: R. Hofstetter)

\section{The use of native predators}

Biocontrol agents could help reduce the rate of spread of the tree. Classical biological control, which has been used to control exotic organisms across many habitats (Simberloff 2013) involves the import of native enemies from the native range of the invasive organism (Harris 1991). For example, in South Africa, $25 \%$ of the 44 exotic weeds have been completely controlled since 1913 using imported biological agents (Zimmerman et al. 2004). However, this method has plenty of controversies since most natural enemy introduction attempts fail, and a few have had unexpected consequences on non-target organisms (Moran et al. 2005) despite specificity tests (e.g., Taylor and Dhileepan 2018). Specificity tests are conducted to ensure that the natural enemy only feeds on the target species (Marohasy 1998). Many attempts of classical biological in Australia to kill the acacia have not produced satisfied results (Mohyuddin 1981; Marohasy 1995; 1994; 1993; Stals 1997; Dhileepan et al. 2006; 2009; 2013; 2014; 2018; Radford et al. 2001; Palmer et al. 2005; 2007; 2012; Willson 1984; Palmer and Senaratne 2007; Taylor and Dhileepan 2013; Kriticos et al. 1999). However, if the objective is to reduce the plant reproductive fitness then targeting propagules (i.e. seeds) is important in limiting the invasion of the tree. The use of seed-destroying biological control agents could reduce the rate of establishment and spread of seedlings (Janzen 1971; Moody and Mack 1988), diminishing seed banks within soil, and reducing the numbers of seedlings recruited into the population (Impson and Hoffmann 2019). South Africa is currently using seed predators for the biological control of invasive Australian acacias (Impson et al. 2009; Strydom et al. 2019). Portugal is using a bud-galling wasp to control invasive acacia and is currently investigating the use of seed predators (Marchante et al. 2011; Marchante et al. 2017).

Native biological control agents may be effective if the native agents are reared in large numbers. The release of large numbers of native agents is called Augmentative
Biocontrol (Simberloff 2013). The method can be effective; for instance, in 1994, Thailand was able to control water lettuce and water hyacinth using Spodoptera pectinicornis, a noctuid moth that eats the plants (Napompeth 1991). A native fungus, Puccinia komarovii, successfully controlled Impatients parviflora in Slovakia (Bacigalova et al. 1998). In Indonesia, authorities in Komodo National Park unintentionally controlled Opuntia cochenillifera by spreading native whiteflies which fed on plants (Heru 2010). A similar effort can be applied by BNP authorities in the future to control prickly acacia. Factors that need to be considered to ensure successful augmentation are: the agent feeding preference, environmental conditions, lifehistory traits, and their effect on target plant (Confrancesco 2000). In Australia, there are 42 known phytophagous insects associated with the prickly acacia (Palmer et al. 2005). This number is significantly lower than in the native range of the prickly acacia which ranges between 64 to over 400 species (Palmer et al. 2005). Interestingly, a native cicada, Cicadetta oldfieldi is known to cause dieback in Australia (Tomley 1995 in Palmer et al 2005). The fungi Botryosphaeria mamane and Lasiodiplodia pseudotheobromae are suspected to cause stem lesions and dieback in Australia (Haque et al. 2019). In Pakistan, several fungi (Drechslera australiensis, Aspergillus flavus, Rhizopus and Alternaria alternata) contribute to the decline of the tree in its native range (Ahmad et al. 2017). Further research is needed to test their effectiveness as biocontrol agents.

Using native species as a biocontrol agent is not free from risks, as biocontrol agents can also become invasive and wreak havoc on the ecosystem. A careful assessment, which is usually conducted on non-native biocontrol agents, should be conducted on native agents particularly if introduced into habitats where it currently does not exist in high numbers (Taylor and Dhileepan 2018). These data include knowledge regarding the target species and the prospective agent, the phylogenetic distance between the target species and commercially important species, the phylogenetic distance between the target species with native and non-native species and knowledge regarding the prospective specificity of the agent, using a screening test (Moran et al. 2005). Phylogenetic criteria are important because closely related species usually share similar niches (Burns and Strauss 2011).

\section{The use of native plants competitors}

Invasive species generally have greater phenotypic plasticity than co-occurring non-invasive species yet noninvasives are able to maintain fitness homeostasis better than invasive species under limited resources or stressful conditions (Davidson et al. 2011). Additionally, native species may undergo coevolution processes with invasives which make them potential competitors (Leger and Espeland 2010). The authorities in BNP have planted native grasses to restore the ecosystem, provide food for ungulates and provided shelter trees to protect animal in dry season. Such grasses could be effective competitors of A. nilotica or help reduce its rate of spread in the park. 
There is evidence that grasses and trees can outcompete A. nilotica. For example, as the prickly acacia seedlings are shade-intolerant (Pellew 1983), particular shade tree species could be planted within the post-cleared area to prevent re-establishment. Seedlings of these shade trees should be planted in the nursery bed first and later transplanted in the field to ensure successful establishment. Grass seeds that can tolerate the presence of the prickly acacia or even express allelopathic activities (SanchezMoreira 2003) can also be planted. Several potential grasses include Sclerachne punctata, Brachiaria reptans (BNP 2010a), Oplismenus burmannii, Dichanthium caricosum, Axonopus compressus (Djufri and Wardiah 2017), and Eulalia amaura (Ridwan 2018). Planting these grasses as native competitors along with shade trees may accelerate control efforts or at a minimum slow its spread in some areas of the park. A recent study shows that shade and grass competition reduce the germination rate, length of shoot, root, and number of leaves of A. nilotica seedlings (Ridwan 2018).

\section{The use of microorganisms}

Allelopathic effects of $A$. nilotica can be alleviated by specific soil microorganisms ( $\mathrm{Li}$ et al. 2015) by breaking down the chemical substances into less toxic compounds (Mishra and Nautiyal 2012). However, the use of microorganisms should be done carefully since allelochemicals are also responsible for changing the microbial community in the soil (Barazani and Friedman 1999; Bais et al. 2003). Specific microbial communities may enhance the toxicity of allelochemical substances (Tanrisever 1987). Microorganisms in the soil with long history of invasion are able to significantly decrease the allelopathic effects of nine invasive plant species ( $\mathrm{Li}$ et al. 2015). Identification of microorganismal species between long and short invasion history in the park may reveal specific species that can alleviate allelopathic activity of the acacia.

A diverse group of microorganisms that can enhance the fitness of plants is endophytes (Rodriguez et al. 2008). This group is divided into Clavicipitaceous species, which mainly associate with mutualistic C3 grasses and nonclavicipitaceous species which have a broad host range (Rodriguez et al. 2008). Non-clavicipitaceous species may be important in mitigation strategies of acacia, since BNP is dominated by C4 grasses (Poaceae) (Li et al. 2015). Brachiaria brizantha, a grass in Africa infected with endophytes, is reported to have more resistance against pathogenic fungi (Kelemu et al. 2001).

Table 1. Population number of microorganisms per mg soil of the grass Brachiaria reptans, adult and seedling of Acacia nilotica (Setiawati and Chandra 2001).

\begin{tabular}{lcccc}
\hline plants & Bacteria & Fungi & CSB & PSB \\
\hline Trees of Acacia nilotica & 340 & 720 & 131.5 & 34.5 \\
Seedlings of Acacia nilotica & 165 & 310 & 80 & 23 \\
Brachiaria reptans & 300 & 1030 & 138.5 & 28 \\
\hline
\end{tabular}

To date, only one study of microorganisms on prickly acacia has been conducted in BNP. The research focused on the population of microorganisms (bacteria, fungi, cellulose-CSB, and phosphate solubilizing bacteria-PSB) that live in the acacia and the grass $B$. reptans (Setiawati and Chandra 2001). They found that $B$. reptans had significantly higher numbers of fungi than both acacia's seedling and trees (Table 1), and that seedlings generally had the lowest microorganism abundances (Setiawati and Chandra 2001). No research has investigated the role and interaction of these microorganisms. With more financial resources in the future, proper inventory of microorganisms that live on the root-soil interface and endophytes of the dominant grasses should be conducted. Next, experiments should be conducted to determine if specific microorganisms are able to alter the acacia' allelochemicals into less toxic compounds.

\section{Social methods}

Social methods can be effective, versatile, provide a long-term solution, and easily integrated with other methods. However, it is still overlooked by the authorities of Baluran National Park. There are only a few studies conducted and most of them relate to tree utilization by local people. Meanwhile education and collaboration efforts are hardly explored. We propose that these aspects should be integrated into control efforts.

\section{Centralized tree utilization}

In its native ranges, the prickly acacia is utilized as medicine, animal food, charcoal, furniture, fungicidal, and an algicidal (Duke 1983). Prickly acacia has semi-weight timber and can be made into ship lumber, furniture, and wood decoration (Dorostkar 2015). Recent research shows that the prickly acacia is proven to have benefits such as antimicrobial activity (Banso 2009; Saravanaraja and Nagarajan 2017) and might reduce the bacteria biofilm formation by $25 \%$ (Hago 2018), and act as a fungicide (Khan et al. 2019; Kubura et al. 2018), antioxidant (Agrawal et al. 2010), adhesive of particleboard (Ndiwe et al. 2019), increase insulin in diabetic rats (Asad et al. 2011), eco-friendly dye-absorbent (Santhi et al. 2014), food preservative (Babiker et al. 2019), drugs (Al Nour et al 2019), and even used as nanostructure synthesis (Awad et al. 2019) for medical purposes (Arya et al. 2019).

In BNP, tree utilization is limited to consumption and firewood (Lydiasari 2016). Despite its many benefits, interest in the prickly acacia is declining in Indonesia and is now a cheap and unpopular commodity; For instance, dried acacia seeds cost less than half a dollar (Rp 5000) per kilogram (Birgantoro and Nurrochmat 2007). Hence, local people are reluctant to exploit the trees (BNP Rangers, pers comm). Research should be conducted to reveal other potential uses of the tree to improve the tree's economic value in Indonesia. However, utilization may lead to dependence on prickly acacia and subsequent market forces to encourage establishment and production. Worse, it may further promote its spread when transported from one place to another. Thus, there must be a consensus on the goal of the prickly acacia utilization among stakeholders and the management of the utilization should be centralized. 
Table 2. The comparison of the feasibility of the proposed control method

\begin{tabular}{llcccccc}
\hline & Methods & Cost & Difficulty & Labor & Benefit & Status & Application \\
\hline Physical & Girdling the trunk & $*$ & $*$ & $* * *$ & Short-term & Not conducted yet & Immediate \\
& Manual seedling uprooting & $*$ & $*$ & $* * *$ & Short-term & Conducted & Immediate \\
& Uprooting with winch & $* *$ & $*$ & $* *$ & Short-term & Not conducted yet & Immediate \\
& Defloration & $*$ & $*$ & $* * *$ & Short-term & Not conducted yet & Immediate \\
& Use of fire & $*$ & $* * *$ & $* * *$ & Long-term & Need improvement & Immediate \\
Chemical & Use of biochar & $*$ & $*$ & $* *$ & Short-term & Not conducted yet & Immediate \\
Biological & Use of grass competitor & $* *$ & $* *$ & $* * *$ & Long-term & Need improvement & Immediate \\
& Introducing native predator & $* * *$ & $* * *$ & $* *$ & Long-term & Not conducted yet & Further research \\
& Use of shade trees & $* * *$ & $* *$ & $* * *$ & Long-term & Need improvement & Immediate \\
& Use of microorganism & $* * *$ & $* * *$ & $* *$ & Long-term & Not conducted yet & Further research \\
Social & Centralized trees utilization & $*$ & $*$ & $* *$ & Short-term & Need improvement & Immediate \\
& Education outreach & $*$ & $*$ & $* * *$ & Long-term & Not conducted yet & Immediate \\
& Stakeholder collaboration & $* *$ & $* *$ & $* *$ & Long-term & Need improvement & Immediate \\
\hline
\end{tabular}

\section{Education outreach}

The result of education and social intervention can be indirect and not easily measurable, and outreach may take several generations to be successful (Anderson 2005). Education outreach can be integrated in the form of ecotourism and training. In the Galapagos Island, support for eradicating introduced species often increased after interested stakeholders, citizens and even tourists join a tour on ecotourism (Powell and Ham 2008). Education can also help prevent introductions of invasive organisms. Lastly, education can encourage further support for other mitigation efforts, such as biocontrol (Larson et al. 2011). The use of a biocontrol agent (in this case, beetles) to mitigate invasive leafy spurge in Canada is considered slower compared to mitigation of the same species in North America (Larson et al. 2011).

Whereas, the climate in Canada is more appropriate for the reproduction and spread of the beetles. The only difference between the mitigation strategies between these two areas is that the US involved education outreach programs focused on local stakeholder and ranchers whom were most affected by leafy spurge (Anderson et al. 2003). This led to active participation from the public to control the species (Larson et al. 2011).

In BNP, education efforts are limited to special tours which are only available by visitors' request (mostly by foreigners) and ranger training. Meanwhile, local visitors which are much more common are less educated on this issue and may be unaware of the tour. Rangers are usually trained to help research agencies kill the trees. More social research, involvement, and education should be conducted, and its effectivity should be assessed.

\section{Stakeholder collaboration}

Collaboration will further promote other efforts in a more effective way. For example, in Minnesota (USA), the state government sought the help of recreational boaters and anglers to prevent the introduction of an aquatic invasive snail species that attaches to boats (Jensen 2010).
Self-sponsored overseas volunteers could be another option; this approach has been successfully conducted by Mauritanian Wildlife Foundation (GISP 2011). Volunteers can be utilized to help control the acacia directly or educate the public about invasive species.

Plenty of collaborations have been conducted between BNP and universities, research institutions, government agencies, and NGOs. However, exclusive collaborations with local stakeholders such as ranchers or farmers have not occurred. Furthermore, collaborations are mostly with researchers while education and community empowerment have not been conducted yet.

\section{Integration of control strategies}

The optimum method integration can be seen in Figure 4. The diagram in Figure 4 explains the process that can be accomplished, and at which point integration is needed. However, not all the suggested containment and control strategies of the invasion of prickly acacia are likely practical. Currently, the lack of funds, human resources, and research are the main factors that limit or prevent the control of the acacia. Below in Table 2, we categorize the potential control methods based on expense, difficulty level, and labor requirements. Our assessment is based on published works and personal communication. Some of the methods have been established and need to be maintained or improved. The benefit given from the efforts may be short term i.e. to kill or reduce the viability of the tree, or long term i.e. to restore the ecosystem. The application of the method can be immediate and/or low risk, and methods with high-risk consequences need to be researched further. Authorities may choose to test one of the strategies or integrate two or more of the easiest strategies.

Most physical, chemical, and social strategies can be started immediately (with funding and available labor). Our strongest suggestion is to use the girdling method of mature acacia trees or bark removal as much as 1.5 meters along the trunk, let it die, and cut the trees. The remaining stump should be uprooted with winches. These physical controls 
should target the Bekol, Balanan, and Kramat savannahs where the density of the acacia is highest (red area; Figure. 5 ). While waiting for the trees to die. Defloration should be conducted and native shade tree seeds which are Azadirachta indica, Schleichera oleosa, Acacia leucophloea, and Tamarindus indica could be planted in the nursery beds. Later, shade tree seedlings could be planted in areas of recently killed acacia stands with the addition of biochar made of coconut husk and maize stalk to reduce allelochemicals from past acacia trees. For the seedlings, manual uprooting can be done and native competitive grass seeds which are Sclerachne punctata, Brachiaria reptans, Oplismenus burmannii, Dichantium caricosum, Axonopus compressus, and Eulalia amaura sowed at the sites. Fire regimes should be maintained once the ecosystem is established yet further monitoring should take place.

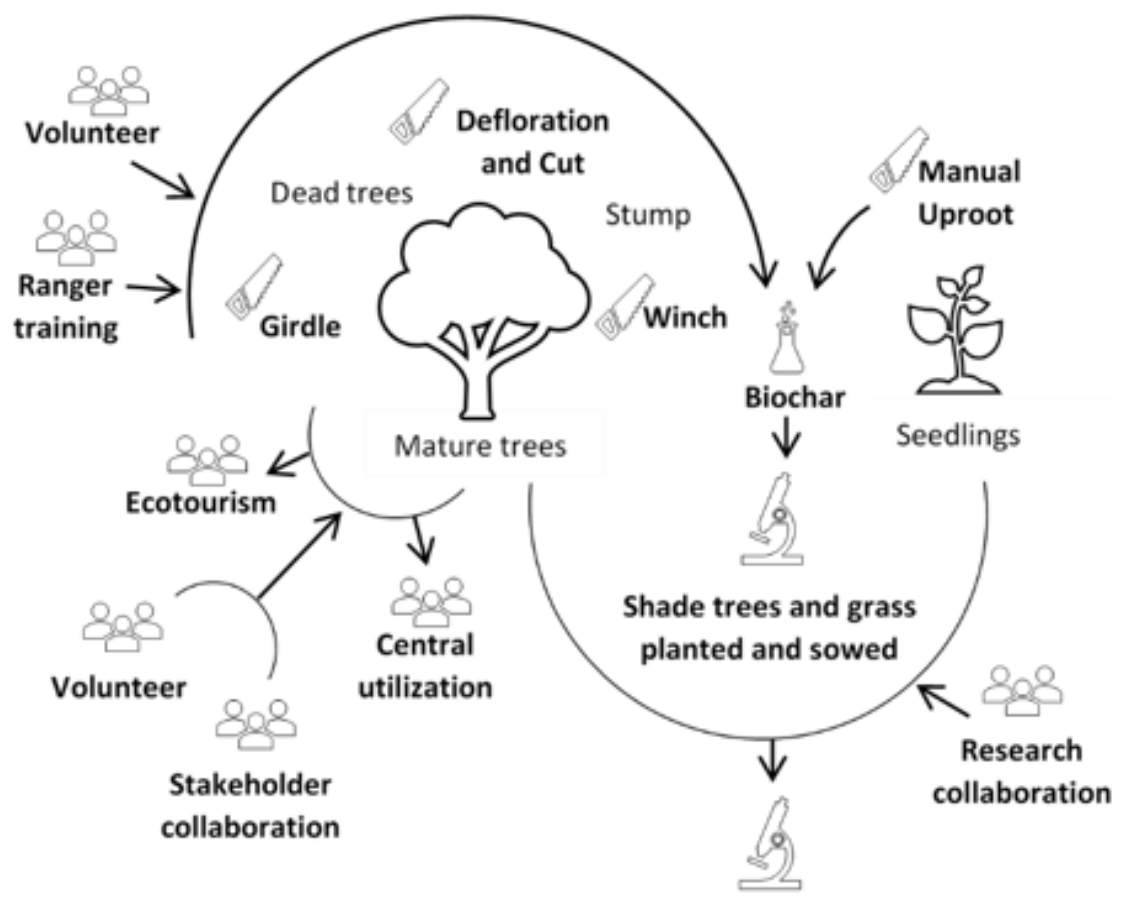

Use of native herbivore and microorganism

Figure 4. Suggested optimum method integration of control strategies of Acacia nilotica
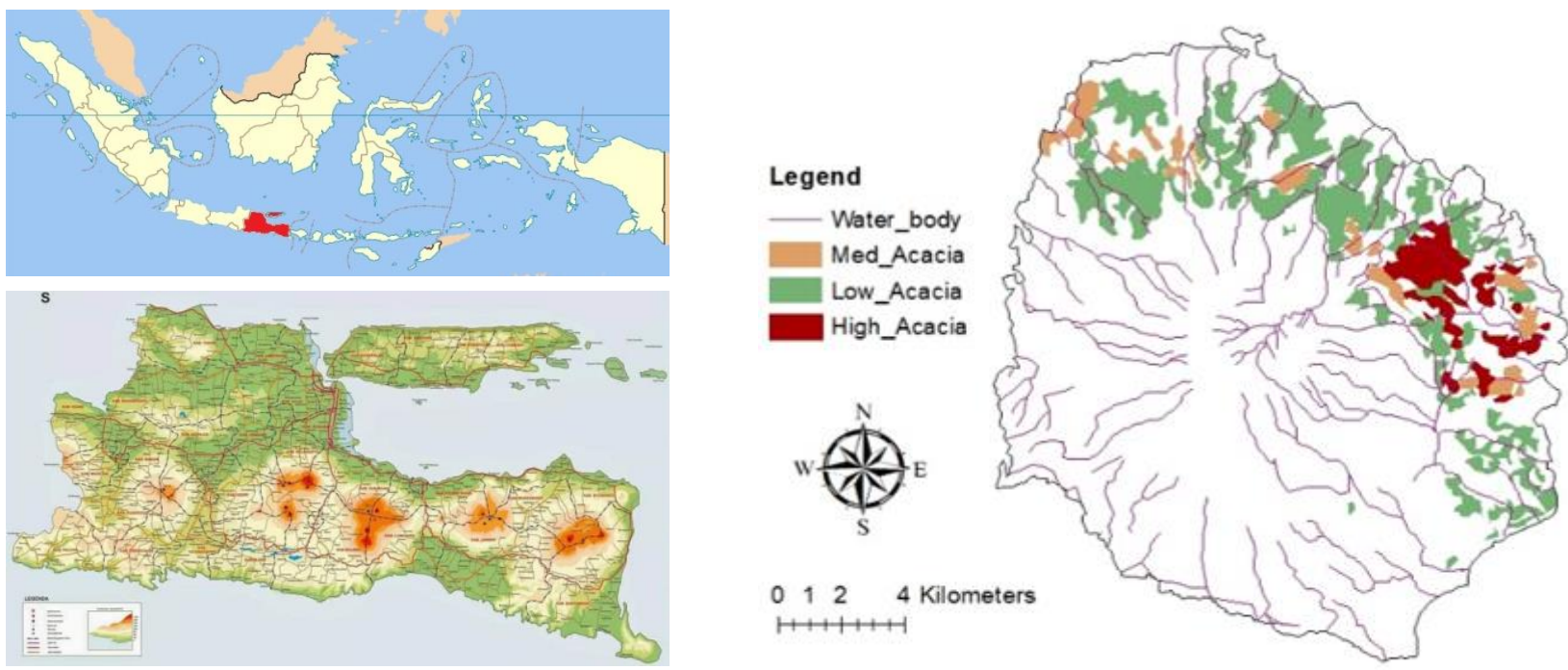

Figure 5. Map of Acacia nilotica density in Baluran National Park (simplified: S. Zahra, source: BNP 2013) 
At the same time, social methods can be conducted in parallel with other efforts. We suggest that BNP produce their own prickly acacia-coffee and edible sprouts to be sold to visitors and advertise it as a local delicacy to increase the demand. We also suggest the BNP give local people access and salary to promote these products in the national park canteen or tourist information center. We hope that having a centralized factory managed by the national park or NGO might prevent the spread of the trees. Additionally, the easiest way to utilize the timber is by producing wood decorations in the shape of BNP fauna as what local people in Komodo National Park did. An agreement to what extent the trees will be utilized should be made to avoid conflict of interest in the future. The initial purpose of utilization should be set as a restoration effort, and economic dependence that may be resulted from tree utilization should be further discussed. For example, if the trees are proven to give a huge benefit for local people, planting the trees in the utilization zone of BNP should be allowed, with the promise that maintenance of the plantation be closely monitored.

Education and volunteer programs could be initiated and conducted in BNP. Authorities could seek help from volunteers and locals to remove dead prickly acacia trees and perform education activities. The use of an information display should be considered at the park entrances to inform visitors and educate them regarding invasive species. Volunteer recruitment should also be conducted since there are plenty of students from local universities that help rangers each year as part of their university courses. Authorities may require tourists to have a short briefing (by local volunteers or student interns) before entering the area. They could also charge a general park fee to help cover costs to control the acacia. Proper training to control and monitor invasive species should be given to all rangers and land managers to ensure the sustainability of control projects. Lastly, land managers should involve local stakeholders who are affected negatively by the invasion such as local ranchers who live close to the national park. These ranchers usually harvest grasses from the boundary area of BNP for their cattle. Involving local stakeholders may create a sense of belonging to the control project which leads to greater participation.

The use of biological strategies may take more research and should be initiated with caution due to potential nontarget effects. Authorities can cooperate with universities to address specific research needs and seek grant funding from the government or overseas institutions. However, the most important part of this control and containment effort is monitoring and data transparency. Every action should be evaluated and published to raise awareness and encourage people to give feedback or appreciation towards the authorities.

\section{Conclusion}

The invasion of $A$. nilotica is truly devastating to the savannah ecosystem in BNP. Recent evidence shows that the tree is slowly moving to eastern parts of Indonesia with Bali and Kupang as a starting point. The invasion should be addressed immediately as it may lead to the loss of savannah ecosystems and biodiversity. All control and containment efforts should be integrated, monitored, evaluated, and published to ensure its sustainability and effectiveness. We hope this paper provides a holistic view of the problem and can help authorities tackle the problem.

\section{ACKNOWLEDGEMENTS}

We thank the School of Forestry NAU, USAID, and CIFOR as the main funder of this research. We also thank NAU writing commons for reviewing this manuscript, as well as Ardiantiono and Sheherazade for their feedback, Muhammad Ridwan and Baluran National Park for providing literature.

\section{REFERENCES}

Ahmad I, Hannan A, Ahmad S, Asif M, Nawaz MF, Tanvir MA, Azhar MF. 2017. Fungi associated with decline of Kikar (Acacia nilotica) and Red River Gum (Eucalyptus camaldulensis) in Faisalabad. Int Scholarly Sci Res Innov 11 (2): 179-182.

Agrawal S, Kulkarni GT, Sharma AN. 2010. A comparative study on the antioxidant activity of methanol extracts of Acacia nilotica and Berberis chitria. Adv Nat Appl Sci 4 (1): 78-85.

Al-Nour MY, Ibrahim MM, Elsaman T. 2019. Ellagic acid, Kaempferol, and Quercetin from Acacia nilotica: Promising combined drug with multiple mechanisms of action. Curr Pharmacol Rep: 1-26.

Alikodra HS. 1987. Tanaman eksotik akasia (Acacia nilotica) dan masalahnya bagi ekosistem savannah di Taman Nasional Baluran. Duta Rimba 13 (19): 30-34. [Indonesian]

Anderson GL, Delfosse ES, Spencer NR, Prosser CW, Richard RD. 2003. Lessons in developing successful invasive weed control programs. J Range Manag 56: 2-12.

Anderson L. W. J. 2005. California's reaction to Caulerpa taxifolia: a model for invasive species rapid response. Biol Invasions 7 (6):10031016

Asad M, Munir TA, Afzal N. 2011. Acacia nilotica leave extract and glyburide: comparison of fasting blood glucose, serum insulin, bThromboglubulin levels and platelet aggregation in Streptozotocininduced diabetic rats. J Pak Med Assoc 61 (3): 247-251.

Arya G, Kumari RM, Pundir R, Chatterjee S, Gupta N, Kumar A, Chandra R, Nimesh S. 2019. Versatile biomedical potential of biosynthesized silver nanoparticles from Acacia nilotica bark. J Appl Biomed 17 (2): 115-124.

Awad MA, Eisa NE, Virk P, Hendi AA, Ortashi KM, Mahgoub AS, Elobeid MA, Eissa FZ. 2019. Green synthesis of gold nanoparticles: preparation, characterization, cytotoxicity, and anti-bacterial activities. Mater Lett 256.

Babiker EE, Al-Juhaimi FY, Alqah HA, Adisa AR, Adiamo OQ, Ahmed IAM, Alsawmahi ON, Ghafoor K, Ozcan MM. 2019. The effect of Acacia nilotica seed extract on the physicochemical, microbiological and oxidative stability of chicken patties. J Food Sci Technol 56 (8): 3910-3920.

Bais HP, Vepachedu R, Gilroy S, Callaway RM, Vivanco JM. 2003. Allelopathy and exotic plant invasion: from molecules and genes to species interactions. Science 301 (5638): 1377-1380.

Bacigalova K, Elias P, Srobarova A. 1998. Puccinia komarovii a rust fungus on Impatiens parviflora in Slovakia. Biologia 53 (1): 7-13.

Baluran National Park (BNP). 1999a. Rancangan Pencabutan Seedling/Anakan Hasil Pembongkaran secara Mekanis, 150 ha di Savannah Bekol [Report]. TN Baluran, Banyuwangi. [Indonesian]

Baluran National Park (BNP). 2004. Laporan Kegiatan Pembakaran Terkendali Petak II Savannah Bekol Dalam Rangka Pembinaan Habitat [Report]. TN Baluran, Banyuwangi. [Indonesian] 
Baluran National Park (BNP). 2005. Laporan Kegiatan Rehabilitasi Savannah Bekol dengan Pemberantan Gulma [Report]. TN Baluran, Banyuwangi. [Indonesian]

Baluran National Park (BNP). 2006a. Laporan Kegiatan Penggunaan Accu zuur dalam Rangka Pemberantasan Seedling dan Trubusan Acacia nilotica [Report]. TN Baluran, Banyuwangi. [Indonesian]

Baluran National Park (BNP). 2006b. Laporan Kegiatan Upaya Pengendalian Acacia nilotica Melalui Pecabutan Seedling [Report]. TN Baluran, Banyuwangi. [Indonesian]

Baluran National Park (BNP). 2006c. Pengumpulan Data dan Informasi Produktifitas Savannah Bekol pada Musim Kemarau [Report]. TN Baluran, Banyuwangi. [Indonesian]

Baluran National Park (BNP). 2007a. Laporan Kegiatan Pembinaan Habitat Savannah Melalui Pencabutan Semai dan Trubus Akasia (Acacia nilotica) [Report]. TN Baluran, Banyuwangi. [Indonesian]

Baluran National Park (BNP). 2010. Monitoring dan evaluasi penanaman bibit pohon shelter di Savannah Bekol [Report]. TN Baluran. [Indonesian]

Baluran National Park (BNP). 2010a. Analisis Vegetasi di Savannah Bekol [Report]. TN Baluran, Banyuwangi. [Indonesian]

Baluran National Park (BNP). 2013. Laporan Kegiatan Pemetaan Sebaran Acacia nilotica di Taman Nasional Baluran [Report]. TN Baluran, Banyuwangi. [Indonesian].

Baluran National Park (BNP). 2017. Pemulihan Ekosistem Savannah Akibat Invasi Acacia nilotica di Taman Nasional Baluran [Report] TN Baluran, Banyuwangi. [Indonesian]

Banso A. 2009. Phytochemical and antibacterial investigation of bark extracts of Acacia nilotica. J Med Plants Res 3 (2): 82-85.

Barazani O, Friedman J. 1999. Allelopathic bacteria and their impact on higher plants. Crit Rev Plant Sci 18: 741-755.

Bergmark CL, Jackson WA, Volk RJ, Blum U. 1992. Differential inhibition by ferulic acid of nitrate and ammonium uptake in Zea mays L. Plant Physiol 98: 639-645.

BirdLife International. 2018a. Pavo muticus. The IUCN Red List of Threatened Species, IUCN, Gland, Switzerland.

BirdLife International. 2018b. Buceros rhinoceros. The IUCN Red List of Threatened Species, IUCN, Gland, Switzerland.

Birgantoro BA, Nurrocmat DR. 2007. Pemanfaatan sumberdaya hutan oleh masyarakat di KPH Banyuwangi Utara. Jurnal Manajemen Hutan Tropika 13 (3): 172-181. [Indonesian]

Brown JR, Carter J. 1998. Spatial and temporal patterns of exotic shrub invasion in an Australian tropical grassland. Landsc Ecol 13: 93-102.

Burns JH, Strauss SY. 2011. More closely related species are more ecologically similar in an experimental test. Proc Nat Acad Sci USA 108: 5302-5307.

Campbell S, McMillan H, Brazier D, Setter M, Setter SD. 2019. Advancing splatter gun technology for rangeland weeds. PAWS 2019: 101

Caesariantika E, Kondo T, Nakagoshi N. 2011. Impact of Acacia nilotica (L.) Willd. ex Del invasion on plant species diversity in the Bekol Savannah, Baluran National Park, East Java, Indonesia. Tropics 20 (2): 45-53.

Choudhari SW, Chopde T, Mane AP, Shambharkar AB, Konde NM, Wahurwagh SR, Taide YB, Gawande SC, Walke RD. 2019. Allelopathic effects of Acacia nilotica (L.) Leaf leachate with emphasis on Trigonella foenum graceum L. (fenugreek). J Pharmacogn Phytochem 8 (1): 500-506.

Coates-Palgrave K. 1984. The trees of southern Africa. Struik, Cape Town, SA.

Confrancesco AF. 2000. Factors to consider when using native biological control organisms to manage exotic plants. J Aquat Plant Manag 38 $117-120$

Cruz Ortega R, Anaya AL, Ramos L. 1988. Effects of allelopathic compounds of corn pollen on respiration and cell division of watermelon. J Chem Ecol 14: 71-86.

Davidson AM, Jennions M, Nicotra AB. 2011. Do invasive species show higher phenotypic plasticity than native species and if so, is it adaptive? A meta-analysis. Ecol Lett14: 419-431.

Dhileepan K, Shi B, Callander J, Teshome M, Neser S, Senaratne KADW. 2018. Gall Thrips Acaciothrips ebneri (Thysanoptera Phlaeothripidae) from Ethiopia, a promising biological control agent for prickly acacia in Australia. Afr Entomol 26 (1): 237-241.

Dhileepan K, Taylor DBJ, Lockett CJ, Balu A, Seier MK, Murugesan S, Tanner RA, Pollard KM, Kumaran N, Neser S. 2014. Biologica control of prickly acacia (Acacia nilotica subsp. indica): current research and future prospects. In: Impson FAC, Kleinjan CA,
Hoffmann JF (eds.). Proceedings of the XIV International Symposium of Biological Control of Weeds. University of Cape Town, South Africa.

Dhileepan K, Balu A, Senthilkumar P, Murugesan M, Shivas R. 2013. Survey and prioritisation of potential biological control agents for prickly acacia (Acacia nilotica ssp. indica) from southern India. Biocontrol Sci Technol 23: 646-664.

Dhileepan K, Lockett C, Robinson M, Pukallus K. 2009. Prioritising potential guilds of specialist herbivores as biological control agents for prickly acacia through simulated herbivory. Ann Appl Biol 154: 97-105.

Dhileepan K, Wilmot KADW, Raghu S. 2006. A systematic approach to biological control agent exploration and selection for prickly acacia (Acacia nilotica ssp. indica). Austr J Entomol 45: 303-307.

Djufri W, 2017. The diversity of undergrowth plants on Acacia nilotica stands as food resources of banteng (Bos javanicus) in Baluran National Park, East Java, Indonesia. Biodiversitas 18 (1): 288-294. [Indonesian]

Djufri W. 2012. Autecology of Akasia (Acacia nilotica) (1. J) Willd. Ex Del. in Baluran National Park, East Java. Jurnal Ilmiah Pendidikan Biologi, Biologi Edukasi 4 (1): 46-55. [Indonesian]

Djufri. 2004. Acacia nilotica (L.) Willd. ex Del. dan Permasalahannya di Taman Nasional Baluran Jawa Timur. Biodiversitas 5 (2): 96-104. [Indonesian]

Dorostkar A. 2015. Investigating the properties of "Acacia nilotica" as a species with capability of utilization in furniture industry. Intl J Innov Sci Eng Technol Eng Tech 1 (10): 748-752.

Duke JA. 1983. Handbook of Energy Crops. Center for New Crops \& Plant Products, Purdue University, USA.

Einhellig FA. 1995. Allelopathy-current status and future goals. In: Inderjit A, Dakshini KMM, Einhellig FA (eds.). Allelopathy: Organisms, Processes, and Applications. American Chemical Society Press, Washington, DC.

Fagg CW. 1992. Acacia nilotica-pioneer for drylands. NFT Highlights June 1992. NFTA: 92-04

Gardner P, Hedges S, Pudyatmoko S, Gray TNE, Timmins RJ. 2016. Bos javanicus. The IUCN Red List of Threatened Species, IUCN, Gland, Switzerland.

Garsetiasih R, Siubelan H. 2005. The invasion of Acacia nilotica in Baluran National Park, East Java, and its control measures. Proc AsiaPacific For Invasive Species Conf. FAO Regional Office for Asia and the Pacific, Bangkok.

Global Invasive Species Programme (GISP). 2001. Invasive Alien Species: A tool kit of best prevention and management practices. CAB International, United Kingdom.

Giri B, Kapoor R, Mukerji KG. 2007. Improved tolerance of Acacia nilotica to salt stress by arbuscular mycorrhiza, Glomus fasciculatum may be partly related to elevated $\mathrm{K} / \mathrm{Na}$ ratios in root and shoot tissues. Microb Ecol 54: 753-760.

Hakim L, Guntoro DA, Waluyo J, Sulastini D, Hartanto L, Nakagoshi N. 2015. Recent status of Banteng (Bos Javanicus) conservation in East Java and its perspectives on ecotourism planning. J Trop Life Sci 5 (3): 152-157.

Hago ZEM. 2018. Antimicrobial activity of Acacia nilotica bee honey on biofilms forming Staphylococcus aureus isolated from Wound Swabs [Dissertation]. Sudan University of Science \& Technology, Kharthoum.

Haque A, van Klinken RD, Goulter K, Galea AJ. 2019. Assessing the potential of fungi isolated from dieback-affected trees as biological control agents for prickly acacia (Vachellia nilotica subsp. indica). BioControl 64 (2) 197-208.

Harris P. 1991. Classical biocontrol of weeds: Its definitions, selection of effective agents, and administrative-political problems. Can Entomol 123: 827-849.

Harvey GJ. 1981. Recovery and viability of prickly acacia (Acacia nilotica) seed ingested by sheep and cattle. Proceedings 6th Australian Weeds Conference, Gold Coast 1: 197-201. Weed Science Society of Queensland, Brisbane.

Hernowo JB, Alikodra HS, Mardiastuti A, Kusmana C. 2011. Population analysis of the Javan green peafowl (Pavo muticus muticus Linnaeus 1758) in Baluran and Alas Purwo National Parks, East Java. Biodiversitas 12 (2): 99-106. [Indonesian]

Heru R. 2010. Pengendalian Kaktus di Loh Buaya. Buletin Varanus 3. Balai Taman Nasional Komodo, Labuan Bajo. [Indonesian] 
Hussain I, Baloch M, Khan, EA, Khan AA. 2019. Morphological and physiological response of maize to some allelopathic plant extracts. Pak J Weed Sci Res 25 (2): 137.

Impson FA, Hoffmann JH. 2019. The efficacy of three seed-destroying Melanterius weevil species (Curculionidae) as biological control agents of invasive Australian Acacia trees (Fabaceae) in South Africa. Biol Control 132: 1-7.

Impson F, Hoffmann J, Kleinjan C. 2009. Australian Acacia species (Mimosaceae) in South Africa. In: Muniappan R, Reddy GA, Raman A (eds.). Biological Control of Tropical Weeds using Arthropods, Cambridge University Press, UK

Invasoras. 2012. Control Method. http://invasoras.pt/en/gallery2/ring barking/. [29 November 2018].

Javaid A, Akhtar N. 2006. Kikar (Acacia nilotica) dieback in Punjab, Pakistan. Pak J Phytopathol 18 (2): 161-165.

Janzen DH. 1971. Seed predation by animals. Ann Rev Ecol Syst 2: 465 492.

Jensen DA. 2010. Assessing the effectiveness of aquatic invasive species outreach influencing boater behaviour in five states. [Thesis] University of Minnesota, Duluth, USA.

Kamler JF, Songsasen N, Jenks K, Srivathsa A, Sheng L, Kunkel K. 2015. Cuon alpinus. The IUCN Red List of Threatened Species, IUCN, Gland, Switzerland.

Kapoor S, Harsh NSK, Sharma SK. 2004. A new wilt disease of Acacia nilotica caused by Fusarium oxysporum. J Trop For Sci 16 (4): 453 462.

Kaushik JC, Mandal BS. 2005. The role of mycorrhiza in tree management for seedling growth of Dalbergia sissoo and Acacia nilotica. Bull Rebecca-Natl Inst Educat 15: 133-137.

Kelemu S, White JF Jr., Muñoz F, Takayama Y. 2001. An endophyte of the tropical forage grass Brachiaria brizantha: Isolating, identifying, and characterizing the fungus, and determining its antimycotic properties. Can J Microbiol47 (1): 55-62.

Khan RAA, Ghazanfar MU, Raza W. 2019. Eco-friendly management of Phytophthora infestans causing late blight of potato. Intl J Bot Stud 4 (2): 144-147.

Kriticos D, Brown J, Radford I, Nicholas M. 1999. Plant population ecology and biological control: Acacia nilotica as a case study. Biol Control 16 (2): 230-239.

Kriticos DJ, Sutherst RW, Brown JR, Adkins SW, Maywald GF. 2003. Climate change and the potential distribution of an invasive alien plant: Acacia nilotica ssp. indica in Australia. J Appl Ecol 40 (1): 111-124

Kubura AK, Omoniyi AM, Olayiwola AH. 2018. Antifungal efficacy of three plant extracts in the suppression of panama disease in banana plants. GSC Biol Pharmaceut Sci 5 (1): 95-103

Kyalangalilwa B, Boatwright JS, Daru BH, Maurin O, van der Bank M. 2013. Phylogenetic position and revised classification of Acacia s.l. (Fabaceae: Mimosoideae) in Africa, including new combinations in Acacia and Senegalia. Bot J Linn Soc 72 (4): 500-523.

Lal B, Khana S. 1993. Renodulation and nitrogen-fixing potential of Acacia nilotica inoculated with Rhizobium isolates. Can J Microbiol 39 (1): 87-91.

Lamprey HF, Halevy G, Makacha S. 1974. Interactions between acacia, Bruchid beetles and large herbivores. East Afr Wildlife J 12: 81-85.

Larson DL, Phillips-Mao L, Quiram G, Sharpe L, Stark R, Sugita S, Weiler A. 2011. A framework for sustainable invasive species management: environmental, social, and economic objectives. J Environ Manag 92: 14-22.

Latif S, Chiapusio G, Weston LA. 2017. Allelopathy and the role of allelochemicals in plant defence. Adv Bot Res 82:19-54

Leger EA, Espeland EK. 2010. Coevolution between native and invasive plant competitors: implications for invasive species management. Evol Appl 3: 169-178.

Li YP, Feng YL, Chen YJ, Tian YH. 2015. Soil microbes alleviate allelopathy of invasive plants. Sci Bull 60 (12): 1083-1091.

Lin WX, Kim KU, Shin DH. 2000. Rice allelopathic potential and its modes of action on Barnyardgrass (Echinochloa crus-galli). Allelopathy J 7: 215-224.

Lydiasari R. 2016. Nilai manfaat taman nasional baluran bagi masyarakat Desa Sumberwaru, Kabupaten Situbondo, Jawa Timur. [Thesis]. Institut Pertanian Bogor, Bogor. [Indonesian]

Malan E. 1991. Derivatives of (+)-catechin-5-gallate from the bark of Acacia nilotica. Phytochemistry 30 (8): 2737-2739.

March N, Vogler W. 2018. Drive-by shooting: Increasing weed treatment speeds using a scattergun. In: 21st Australasian Weeds Conference.
Marchante H, Freitas H, Hoffmann JH. 2011. Assessing the suitability and safety of a well-known bud-galling wasp, Trichilogaster acaciaelongifoliae, for biological control of Acacia longifolia in Portugal. Biol Control 56: 193-201.

Marchante H, López-Nunez FA, Freitas H, Hoffmann JH, Impson F, Marchante E. 2017. First report of the establishment of the biocontrol agent Trichilogaster acaciaelongifoliae for control of invasive Acacia longifolia in Portugal. EPPO Bull. DOI: 10.1111/epp.12373.

Marohasy J. 1998. The design and interpretation of host specificity tests for weed biological control with particular reference to insect behavior. Biocontrol News Inform 19 (1): 13-20.

Marohasy J. 1995. Prospects for the biological control of prickly acacia, Acacia nilotica (L.L Willd. ex Del. (Mimoseceae) in Australia. Plant Protec Quart 10 (1): 24-31.

Marohasy J. 1994. Biocontrol of Acacia nilotica using insects from Kenya. Final report to Australian Wool Corporation. Sherwood, Alan Fletcher Research Station, Queensland Department of Lands, Brisbane.

Marohasy J. 1993. Biocontrol of Acacia nilotica using insects from Kenya. Final report to Australian Wool Corporation. Sherwood, Alan Fletcher Research Station, Queensland Department of Lands, Brisbane.

Meazza G, Scheffler BE, Tellez MR, Rimando AM, Romagni JG, Duke SO. 2002. The inhibitory activity of natural products on plant phydroxyphenylpyruvate dioxygenase. Phytochemistry 60 (3): 281288.

Miller MF. 1994a. Large African herbivores, bruchid beetles and their interactions with Acacia seeds. Oecologia 97: 265-270.

Miller MF. 1994b. The costs and benefits of Acacia seed consumption by ungulates. Oikos 71 (1): 181-187.

Miller MF. 1994c. Acacia seed survival, germination and seedling growth following pod ingestion by large herbivores and seed chewing by rodents. Afr J Ecol 33 (3): 194-210.

Miller MF. 1996. Dispersal of Acacia seeds by ungulates and ostriches in an African savannah. J Trop Ecol 12 (3): 345-356.

Miller MF, Coe M. 1993. Is it advantageous for Acacia seeds to be eaten by ungulates? Oikos 66 (2): 364-368.

Mirnawati RP, Suwastika IN. 2017. Effectiveness of leaf extract of Lantana camara $\mathrm{L}$. as a natural herbicide against seed germination of Acacia nilotica (L.) Willd. Ex Delile. Natl Sci J Sci Technol 6 (2): 116-128.

Mishra S, Nautiyal CS. 2012. Reducing the allelopathic effect of Parthenium hysterophorus L. on wheat (Triticum aestivum L.) by Pseudomonas putida. Plant Growth Regul 66: 155-165.

Mohyuddin AI. 1981. Phytophages associated with Acacia nilotica in Pakistan and possibilities of their introduction into Australia. 161166. In: Del Fosse ES (eds.). Fifth International Symposium on Biological Control of Weeds. CSIRO, Melbourne.

Moody ME, Mack RN. 1988. Controlling the spread of plant invasions: the importance of nascent foci. J Appl Ecol 25: 1009-1021

Moran AC, Hoffmann JH, Zimmermann HG. 2005. Biological control of invasive alien plants in South Africa: necessity, circumspection, and success. Frontiers Ecol Environ 3 (2): 71-77.

Napompeth B. 1991. Aquatic weed management by biological methods in Thailand. Aquat Weed Manag Biol Methods Thai 40: 51-61.

Nazif M. 1988. The trial of control of Acacia nilotica with herbicides Indamin $720 \mathrm{HC}$, Garlon $480 \mathrm{Ec}$ and trusi at Baluran National Park. Forest Research Bulletin No. 490, Bogor. [Indonesian]

Ndiwe B, Pizzi A, Danwe R, Tibi B, Konai N, Amirou S. 2019. Particleboard bonded with bio-hardeners of tannin adhesives. Eur J Wood Wood Prod. DOI: 10.1007/s00107-019-01460-5.

Nijman A, Supriatna J. 2008. Trachypithecus auratus. The IUCN Red List of Threatened Species, IUCN, Gland, Switzerland.

Nishida N, Tamotsu S, Nagata N, Saito C, Sakai A. 2005. Allelopathic effects of volatile monoterpenoids produced by Salvia leucophylla: Inhibition of cell proliferation and DNA synthesis in the root apical meristem of Brassica campestris seedlings. J Chem Ecol 31 (5): 1187-1203.

Padmanaba M, Tomlinson KW, Hughes AC, Corlett RT. 2017. Alien plant invasions of protected areas in Java, Indonesia. Sci Rep 7: 1-11

Palmer B, Lockett C, Dhileepan K. 2012. Acacia nilotica subsp. indica (Benth.) Brenan-prickly acacia. In: Julien M, Cruttwell McFadyen R, Cullen J (eds) Biological Control of Weeds in Australia. CSIRO, Melbourne

Palmer WA, Lockett CJ, Senaratne KADW, McLennan A. 2007. The introduction and release of Chiasmia inconspicua and C. assimilis 
(Lepidoptera: Geometridae) for the biological control of Acacia nilotica in Australia. Biol Control 41 (3): 368-378.

Palmer WA, Senaratne KADW. 2007. The host range and biology of Cometaster pyrula; a biocontrol agent for Acacia nilotica subsp. indica in Australia. Biocontrol 52 (1): 129-143.

Palmer WA, Vitelli MP, Donnelly GP. 2005. The phytophagous insect fauna associated with Acacia nilotica ssp. indica (Mimosaceae) In Australia. Austral Entomol 32 (4): 173-180.

Pellew RA. 1983. The giraffe and its food resources in the Serengeti. Response of the giraffe population to changes in the food supply. Afr J Ecol 21: 269-283.

Pillai SRM, Gopi KC. 1990. The bagworm Pteroma plagiophleps Hamp. (Lepidoptera, Psychidae) attack on Acacia nilotica (Linn.) Wild. ex Del. Indian For 116 (7): 581-583.

Powell RB, Ham SH. 2008. Can ecotourism interpretation really lead to pro-conservation knowledge, attitudes, and behavior? Evidence from the Galapagos Islands. J Sustain Tourism 16 (4): 467-489.

Pratama MA. 2014. Acacia nilotica's pod pest insect identification as conservation basic in Baluran National Park, Indonesia [Thesis] University of Jember, Jember. [Indonesian]

Qirom MA, Andriani S, Azwar F, Octavia D. 2007. Release cutting effect of Acacia nilotica (L.) Willd.ex Del on species composition and quality of savannah in Baluran National Park of East Java. Jurnal Penelitian Hutan dan Konservasi Alam 4 (6): 573-582. [Indonesian]

Radford IJ, Nicholas DM, Brown JR. 2001. Assessment of the biological control impact of seed predators on the invasive shrub Acacia nilotica (Prickly Acacia) in Australia. Biol Control 20 (3): 261-268.

Ridwan M. 2018. The establishment of Acacia nilotica under shading, grass competition and dung fertilizer in a savanna ecosystem, Baluran National Park, Indonesia. [Thesis]. University of Wageningen, Netherland.

Rizvi SJH, Haque H, Singh AK, Rizvi A. 1992. A discipline called allelopathy. In: Rizvi SJH, Rizvi A (eds) Allelopathy: Basic and applied aspects. Chapman \& Hall, London.

Rodriguez RJ, White JF Jr, Arnold AE, Redman RW. 2008. Fungal endophytes: diversity and functional roles. New Phytol 182: 314-330.

Sanchez-Moreira AM, Weiss OA, Regiose-Roger MJ. 2003. Allelopathic evidence in the Poaceae. Bot Rev, Bronx 69 (3): 300-319.

Santhi T, Prasad AL, Manonmani S. 2014. A comparative study of microwave and chemically treated Acacia nilotica leaf as an ecofriendly adsorbent for the removal of rhodamine B dye from aqueous solution. Arabian J Chem 7 (4):.494-503.

Samsoedin I, Siregar CA. 1997. The characteristic of soil chemical that invaded by Acacia nilotica at Baluran National Park, East Java. Forest and Nature Conservation Research and Development Centre, Bogor.

Saravanaraja M, Nagarajan K. 2017. An appraisal on supreme pharmacological and minutest ecological prospective of Acacia nilotica (L.) Del. Asian J Pharm Pharmacol 3 (3): 61-65.

Sastrapradja S. 1978. Tanaman Obat. Lembaga Biologi Nasional, LIPI, Bogor. [Indonesian]

Schmidt LH, Mbora A. 2008. Acacia nilotica (L.) Del. Seed Leaflet 137: $1-8$.

Schuurmans H. 1993. Acacia nilotica (L.) Willd. Ex Del: Ecology and Management: a Study to an Introduced, Colonizing Plant Species in Baluran National Park, Java, Indonesia. Agricultural University Wageningen, The Nederlands.

Setiabudi S, Tjitrosoedirdjo S, Mawardi I, Saiful. 2013. Invasion of Acacia nilotica into savannahs inside Baluran National Park, Eas Java, Indonesia. Proc. 24th Asian-Pacific Weed Science Society Conference, Bandung, Indonesia. [Indonesian]

Setiawati T, Chandra T. 2001. Soil microflora population in Bekol Savannah, Baluran National Park Taman. Prosiding Seminar Nasiona Taman Nasional Baluran 1. Universitas Jember, Jember. [Indonesian]

Simberloff D. 2013. Invasive Species: What Everyone Needs to Know? What Everyone Needs to Know. Oxford University Press, Oxford, UK.

Sharma MP, Bhatia NP, Adholeya A. 2001. Mycorrhizal dependency and growth responses of Acacia nilotica and Albizzia lebbeck to inoculation by indigenous AM fungi as influenced by available soil $\mathrm{P}$ levels in a semi-arid alfisol wasteland. New For 21 (1): 89-104.

Stals R. 1997. A survey of phytophagous organisms associated with Acacia nilotica in South Africa. Final Report to the Queensland Department of Natural Resources. ARC-Plant Protection Research Institute, Pretoria, South Africa.

Stein AB, Athreya A, Gerngross P, Balme G, Henschel P, Karanth U, Miquelle D, Rostro-Garcia S, Kamler JF, Laguardia A, Khorozyan I,
Ghoddousi A. 2016. Panthera pardus. The IUCN Red List of Threatened Species, IUCN, Gland, Switzerland.

Strydom M, Veldtman R, Ngwenya MZ, Esler KJ. 2019. Seed survival of Australian Acacia in the Western Cape of South Africa in the presence of biological control agents and given environmental variation. PeerJ 7: e6816. DOI: 10.7717/peerj.6816.

Sugardjito J. 1984. Laporan Survey Satwa Mammalia Besar di Taman Nasional Baluran. Museum Zoologi Bogor, Lembaga Biologi Nasional, LIPI, Bogor. [Indonesian]

Sujeeun L, Thomas SC. 2017. Potential of biochar to mitigate allelopathic effects in tropical island invasive plants: evidence from seed germination trials. Trop Conserv Sci 10: 1-14

Sutomo S, van Etten E. 2017. Species distribution model of invasive alien species Acacia nilotica for Central-Eastern Indonesia using Biodiversity Climate Change Virtual Laboratory (BCCVL). Trop Drylands 1 (1): 36-42.

Sutomo S, van Etten E, Iryadi R. 2019. Use of Landsat imagery to map spread of the invasive alien species Acacia nilotica in Baluran National Park, Indonesia. Biotropia 27 (1): 10.

Tanrisever N, Fronczek FR, Fischer NH, Williamson GB. 1987. Ceratolin and other flavonoids from Ceratiola ericoides. Phytochemistry 26 (1): 175-179.

Taylor DBJ, Dhileepan K. 2013. Life history of Anomalococcus indicus (Hemiptera: Lecanodiaspididae), a potential biological control agent for prickly acacia Vachellia nilotica ssp. indica in Australia. Biocontrol Sci Technol 23 (12):1373-1386.

Taylor DB, Dhileepan K. 2018. The host specificity of Anomalococcus indicus Ayyar (Hemiptera: Lecanodiaspididae), a potential biological control agent for prickly acacia (Vachellia nilotica ssp. indica) in Australia. Biocontrol Sci Technol 28 (11): 1014-1033.

Tewari MC. 1978. Data on Natural Durability of Timber Species (Installed in the Test Yard at New Forest, Dehra Dun) According to 1976 Inspection, Their Treatability and Seasoning Characteristics. IRG/WP/3127. Int Res Group Wood Preservation, Stockholm, Sweden.

Tjitrosoedirdjo S, Mawardi I, Setiabud S., Tjitrosoedirdjo SS, Biotrop J. 2013. Chemical control of Acacia nilotica under medium density regime populations and broadleaved weeds in Bekol savanna, Baluran National Park, East Java Indonesia. In: Weed Science Society Conference October 22-25, 2013, Bandung. [Indonesia]

Tjitrosoedirdjo. 2002. Pemulihan Ekosistem Savannah Akibat Invasi Acacia nilotica di Taman Nasional Baluran. LIPI, Bogor. [Indonesian]

Tybirk K. 1989. Flowering, pollination and seed production of Acacia nilotica. Nordic J Bot 9 (4): 375-381.

Van Etten E. 2016. Effect of fire and digestion by herbivores on seeds of the exotic invasive species Acacia nilotica in savannah at Baluran National Park Indonesia. Austral Plant Conserv 25 (3): 20.

Vitelli JS, Pitt JL. 2006. Assessment of current weed control methods relevant to the management of the biodiversity of Australian rangelands. Rangeland J 28 (1): 37-46.

Wardle DA, Zackrisson O, Nilsson MC. 1998. The charcoal effect in Boreal forests: Mechanisms and ecological consequences. Oecologia 115: 419-426.

Willson BW. 1984, August. The biological control of Acacia nilotica indica in Australia. Proc of the 6th Int Symp Biol Control Weeds: 19-25.

Wilson JR, Gairifo C, Gibson MR, Arianoutsou M, Bakar BB, Baret S, Celesti-Grapow L, DiTomaso JM, Dufour-Dror JM, Kueffer C, Kull CA. 2011. Risk assessment, eradication, and biological control: global efforts to limit Australian acacia invasions. Divers Distrib 17 (5): 1030-1046.

Yang Q, Ye W, Liao F, Yin X. 2005. Effects of allelochemicals on seed germination. Chinese J Ecol 24 (12): 1459-1465.

Zahra S. 2019. The Potency of Insect and Fungi in Baluran National Park as Natural Enemies of Invasive Vachellia nilotica and Its Future Control Strategies. [Thesis]. Northern Arizona University, USA.

Zahran HH. 1999. Rhizobium-legume symbiosis and nitrogen fixation under severe conditions and in an arid climate. Microbiol Mol Biol Rev 63 (4): 968-989.

Zakaria B. 2012. The technique for removing invasive trees of Acacia nilotica (L) Willd.Ex.Del, by using Tiftor in Baluran National Park, East Java. Jurnal Penelitian Hasil Hutan 30 (4): 279-280. [Indonesian]

Zimmermann HG, Hoffmann JH, Moran AC. 2004. Biological control in the management of invasive alien plants in South Africa, and the role of the Working for Water Programme: working for water. South Afr J Sci 100 (1): 34-40. 